\title{
REPRESENTACIÓN INDÍGENA EN EL ÁREA CENTRO-SUR ANDINA. EL CASO DE LOS URU-CHIPAYA
}

\author{
INDIGENOUS REPRESENTATION IN THE SOUTH-CENTRAL ANDEAN REGION. \\ THE CASE OF THE URU-CHIPAYA
}

\author{
Felipe Maturana Díaz*
}

\begin{abstract}
La representación visual indígena en el área Centro-Sur andina sufre un importante cambio con la emergencia de la fotografía etnográfica de principio del siglo XX. Práctica científica que integra las exigencias de la teoría antropológica, con la composición estética-documental y una aproximación prudente y cortés con las comunidades indígenas; configurando una práctica más profunda, humanitaria y artística. Rompiendo el imaginario indígena para el altiplano boliviano heredado del naturalista Alcides D’Orbigny (1847) con su mirada fisiognómica que invisibilizó al indígena, relegándolo a un lugar marginal o pintoresco. También, rompe con el costumbrismo de George Squier (1877) y Charles Wiener (1880), que consolida un imaginario indígena lleno de imponentes ruinas arqueológicas como Sillustani, Tiwanaku y las chullpas de los Carangas, entre muchas. Y, por último, rompe con el modelo antropométrico y su mirada fragmentaria, preocupada del cuerpo como contenedor de sentido e identidad; practicada por la misión Créqui-Montfort (Chervin 1908) y Arthur Posnansky (1915 y 1918). Giro representacional que se evidencia en la fotografía etnográfica de Alfred Métraux entre los chipaya de Carangas (1931), donde la imagen jugó un rol activo en la reactivación de procesos de memoria e identidad que reconfiguraron del imaginario indígena en los Andes Centro-Sur.
\end{abstract}

Palabras claves: Etnografía visual, altiplano, imaginario, Alfred Métraux.

The indigenous visual representation in the South-Central Andean Region, has suffered an important change due to the emergence of the ethnographic photography at the beginning of the 20th century. This scientific practice integrates the anthropological theory requirements, the aesthetic composition of the documentary, and a prudent and courteous approach to the Latin American indigenous communities; configuring a deeper, more humanitarian and artistic ethnographic practice. Breaking the naturalist Alcides D'Orbigny's (1847) indigenous imaginary for the Bolivian Highlands and his views on physiognomics that invisibilized the indigenous people, relegating them to a marginal or picturesque place. It also breaks with the canons set by George Squier (1877) and Charles Wiener (1880), which consolidates an indigenous imagery filled with striking archaeological ruins like Sillustani, Tiwanaku and the chullpas of the Carangas, among many. And, finally, it breaks with the anthropometric model and its fragmented view, concerned with the body as a container of meaning and identity; practiced by the missions of Créqui-Montfort (Chervin 1908) and Arthur Posnansky (1915-1918). Representational turn that becomes evident in the ethnographic photograph of Alfred Métraux amongst the chipaya of Carangas (1931), where the image played an active role in the processes of memory reactivation and identity that reconfigured indigenous imagery in the South-Central Andes.

Key words: Visual ethnography, highland, imaginary, Alfred Métraux.

\section{Introducción}

El mundo andino ha sido dividido tradicionalmente en cuatro áreas: "Andes Septentrional" (principalmente Ecuador), "Andes Central” (norte y centro del Perú) "Andes Centro-Sur" (sur de Perú, altiplano de Bolivia, norte grande de Chile y parte del noroeste de Argentina) y los "Andes Meridionales" (norte chico y centro de Chile y parte del noroeste argentino). Y su representación se ha concentrado en la figura del inca, invisibilizando la diversidad cultural del mundo andino (Hidalgo 1982).

El área Centro-Sur Andina o sector Circumpuneño, se ha identificado históricamente con la cultura Tiwanaku (1), que habitó los alrededores de los lagos Titicaca y Poopó, aproximadamente entre el 300 y 1.100 d.C. Fecha que Tiwanaku pierde el dominio y cede paso a numerosos reinos y señoríos independientes, como Lupacas, Collas, Carangas, Lípez y Omaguacas; entre otros (Figura 1). Los lazos supralocales establecidos en el periodo Tiwanaku y continuados por los "señoríos" étnicos (1.100 d.C.-1.400 d.C.) se fragmentaron en pequeñas unidades territoriales en la Colonia (Sanhueza 2008). Al respecto, Thierry Saignes plantea que los llamados "pueblos de indios" son el resultado del reagrupamiento forzado de las aldeas indígenas, a partir de 1570 . Y que muchas de las

* Universidad de Chile, Programa de Doctorado en Estudios Latinoamericanos (CECLA) / Centro de Estudios en Antropología Visual (CEAVI). Santiago, Chile. Correo electrónico: fmaturanadiaz@ gmail.com 


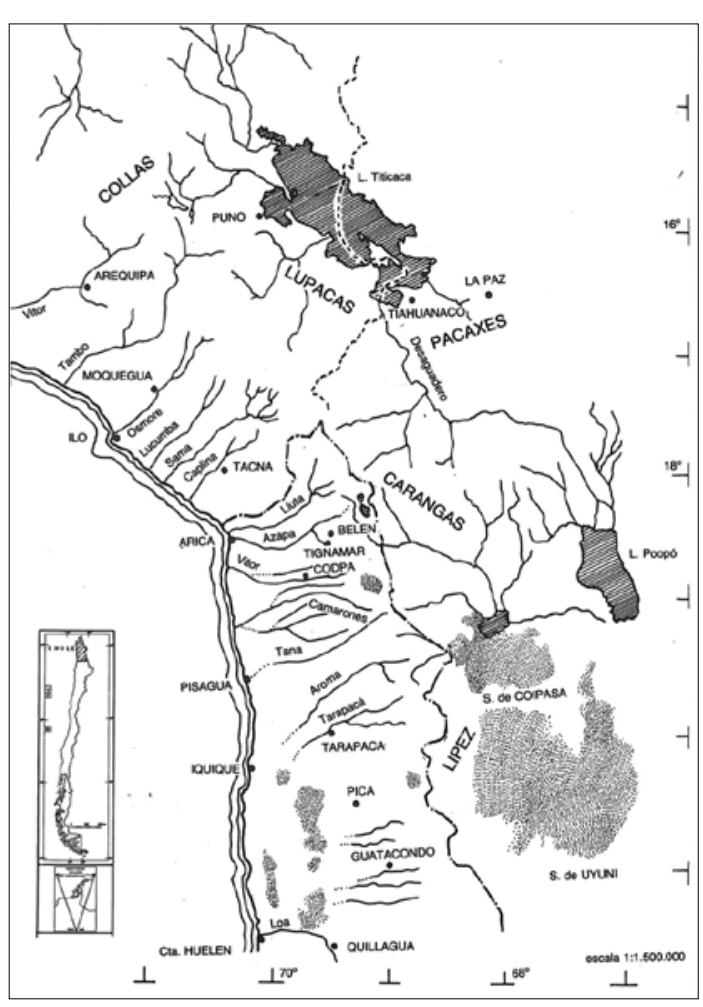

Figura 1. Valles Occidentales y Altiplano Circuntiticaca, Ca. 1.100 d.C. (Hidalgo et al. 1989:189).

denominadas "comunidades andinas", lejos de ser un núcleo duro, prístino e inalterable del mundo precolombino, es el producto de presiones tanto externas como internas. Las primeras, impulsadas por la administración colonial y las repúblicas, tendientes a la uniformidad social y cultural de este segmento poblacional; mientras que las segundas, propias de las dinámicas de resistencia de la población andina, que aceleraron los procesos de diferenciación social y de fragmentación territorial provocando, en algunos casos, hostilidades entre los pueblos y sus comunidades circundantes (Saignes 1991).

Una de las características principales del área Centro-Sur Andina es la alta movilidad poblacional, que integra varios pisos ecológicos, como la costa del Pacífico, los valles u oasis desérticos, la sierra semiárida, la puna salada del altiplano, la selva amazónica y los valles calchaquíes. Estos movimientos de trashumancia (movilidad pastoril) y de control simultáneo de recursos apartados (que Murra ha llamado "verticalidad") conformaron un patrón de poblamiento con espacios económicos compartidos, organizados bajo un sistema dual que divide el mando y las competencias. La vocación de esta región, como activo nudo del tráfico de gentes, productos, ideas y tecnologías ha sido una constante desde los tiempos prehispánicos con poblaciones entretejidas y territorios interdigitados (Tschopik 1946; Hidalgo 1978; Martínez 1992).

Para la zona de estudio destacamos el caso de las comunidades indígenas uru, quienes constituían un cuarto de la población indígena en el siglo XVI; ocupando todo el eje acuático que atraviesa el altiplano andino -río Azángaro, lago Titicaca, río Desaguadero, el lago Poopó, río Lacajahuira y lago Coipasa-. Grupo étnico que sufrió un intenso proceso de transculturación producto de su progresiva aymarización e inserción en el sistema colonial, donde sufrió una gran discriminación; el término uro o uru fue comúnmente usado en el siglo XVII como sinónimo de sucio, harapiento y rústico ( $\mathrm{La}$ Barre 1946; Wachtel 1978).

En el altiplano andino las familias lingüísticas Quechua y Aymara han desplazado a diversas lenguas que eran habladas hasta el siglo XVIII y XIX en este amplio territorio. Hoy solo quedan algunos rastros de estos idiomas en los nombres de lugares y ciertas palabras, y en relictos dialectales como el hablado por los sanadores Callahuaya que mezclan el Puquina (lengua extinta) con el Quecha. El único otro idioma, además del Quechua y el Aymara, que aún se habla en el altiplano boliviano es el Uru-Chipaya. Su relación con otras lenguas como el Arawak, es aún controversial por su grado de incerteza, siendo definida como lenguaje residual "no clasificado". El término uru al parecer sería de origen quechua, vocablo que en general significa "insecto" o "bicho". Pero también significa "persona o animal de tierna edad" o "animal salvaje" (no domesticado), en clara acepción de la inferioridad de este grupo humano, quienes no practicaban la agricultura como medio de subsistencia y no pagaban tributo; es decir, un término despectivo, y no forzosamente un calificativo étnico. Pues no solo los pueblos originarios del lago sino también ciertos ayllu no reales del Cuzco podían ser designados como uru. De este modo, el término uru se convierte tanto en una categoría étnica como también fiscal y tributaria, lo que ha dificultado su definición y estudio. Este sería el caso probable de los Changos de la costa de Tarapacá, llamados también "Uru" por fuentes tempranas, pero cuyo idioma no tendría relación con la lengua uru (Cerrón-Palomino 2006; Dedenbach-Salazar 2007). El etnónimo correcto 
de los uru del Titicaca es Kjotsuñi, que significa "hombre del lago", mientras que el de los chipaya es Jas-shoni, Qnas Soñi o Qhwaz-zh zhoñi, que significa "hombre del agua" (Hannss 2008).

\section{La Representación Visual Indígena en el Área Centro-Sur Andina}

Una de las primeras escenas del mundo andino, que fue ampliamente difundida e impresa en diversas crónicas, es el rechazo del "requerimiento" por parte de Atahualpa (Figura 2). Grabado publicado en 1534, sin autor como portada, en "La conquista del Perú llamada Nueva Castilla" de Cristóbal de Mena y en la "Verdadera relación de la conquista del Perú y provincia del Cuzco" de Francisco de Xerez, ambas impresas en Sevilla. En la imagen se observa a Atahualpa desnudo, llevado en andas por sus siervos, presto a arrojar con la mano la Biblia como signo de rechazo a Dios y portando un cetro y la maskapaycha (insignia de la autoridad del inca

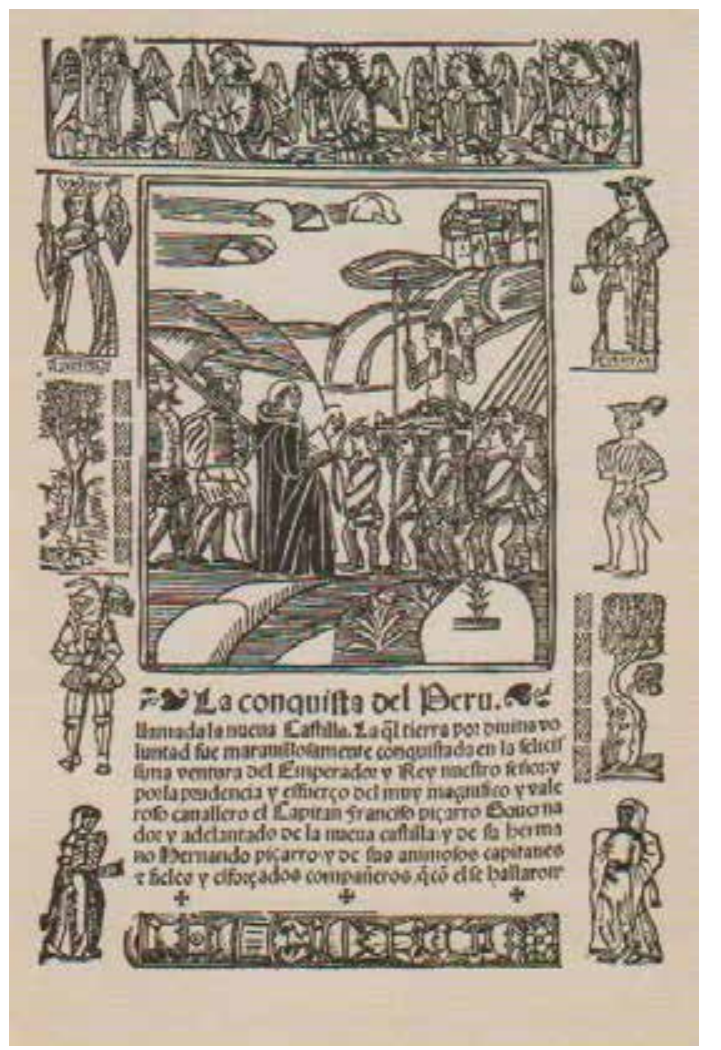

Figura 2. Rechazo de Atahualpa al requerimiento. Portada de "La conquista del Perú llamada Nueva Castilla", de Cristóbal de Mena en 1534 (Estenssoro 2005:98). que consistía en una borla roja que colgaba en la frente del Inca). Signos visuales que permitieron al español unificar el territorio y sus habitantes bajo la figura de Atahualpa como rey, y que fue ampliamente rechazada por la élite cuzqueña y los cada vez más poderosos jefes locales, que consideraban a Atahualpa un bastardo y un traidor (Estenssoro 2005).

En 1569, en un contexto de inestabilidad política en Perú, el virrey Francisco de Toledo mandó a confeccionar la historia del origen y descendencia de los Incas, basado en fuentes indígenas y certificado por los diferentes ayllu (unidad de parentesco básica de la estructura social andina). Una forma, medianamente consensuada, de construir una historia que diera legitimidad al cobro de tributos, mita y reducción territorial impuesta por Toledo y la Corona española. Su resultado fueron dos textos: uno, escrito por el virrey y, otro, por el cosmógrafo Pedro Sarmiento de Gamboa. Más cuatro paños pintados por artistas indígenas, que relatan, visualmente, los mitos de la creación de la humanidad por Viracocha, a orillas del lago Titicaca, y el origen de los Incas en los cerros de Tampu-tocco. Los otros tres lienzos muestran los retratos de los 12 Incas y sus reinas -desde Manco Capac hasta Huáscar-con indicaciones de sus ayllu y sus principales acciones o territorios anexados; el tamaño de los paños oscilaba entre 3 y 4 metros de alto por 4 a 5 metros de ancho. Un discurso textovisual sincrético que tiene como único personaje al inca, condensado en la figura ausente de Atahualpa, quien no fue retratado por ser ilegítimo y asesino de Huáscar (Estenssoro 2005).

En 1615, Felipe Guamán Poma de Ayala, indígena ilustrado del Perú, envía al rey Felipe II un texto de 1.180 páginas -que contiene 398 dibujos- titulado "Nueva Corónica y Buen Gobierno". Un texto visual que integra la historia inca al interior de la historia universal, revalorizando el mundo indígena -como un lugar donde habita la moral, el orden y la cristiandad- y criticando el mundo europeo -representado por la barbarie, la inmoralidad y el caos-. Un límite cultural, que lejos de proponer una asimilación cultural o pérdida cultural, proponen una resistencia y reivindicación de un mundo andino que, sin negar la incorporación de lo occidental, lucha por sus derechos. Un mundo andino representado por el inca, con algunas referencias a los otros pueblos que conformaban el Tawantinsuyu o imperio Inca, 
que aparecen principalmente en los capítulos relativos a ídolos, entierros y fiestas, donde los distintos grupos culturales son posibles de ser identificados por sus gorros o tocados (Horta 2011). Allí, el inca es comparado con los cuatro suyus: chinchasuyu (oeste -hacia el ecuador-), antisuyu (norte -hacia la amazonas-), collasuyu (este-hacia el altiplano-) y cuntisuyu (sur-hacia el mar-). Las imágenes que ilustran los textos usan modalidades representacionales similares, pero con aspectos étnicos distintivos. A nivel de semejanzas, todos ellos ocurren en un espacio exterior, en vinculación con la naturaleza o el territorio; que se opone al espacio europeo/interior (Adorno 1987). A nivel de distinciones, destacan las diferentes indumentarias utilizadas, en una degradación progresiva, que va desde el inca (Figura 3) -que aparece con una rica indumentaria compuesta por el uncu, orejeras, tocado o llautu y sandalias, entre otros- hasta el antisuyu (amazonas), que aparece prácticamente desnudo (Figura 4). Los Collas (Figura 5) visten muy similares a los chincha y cunti, aunque con los cunti comparten un tipo de calzado distinto de los chincha e Inca, pero se distinguen los Collas

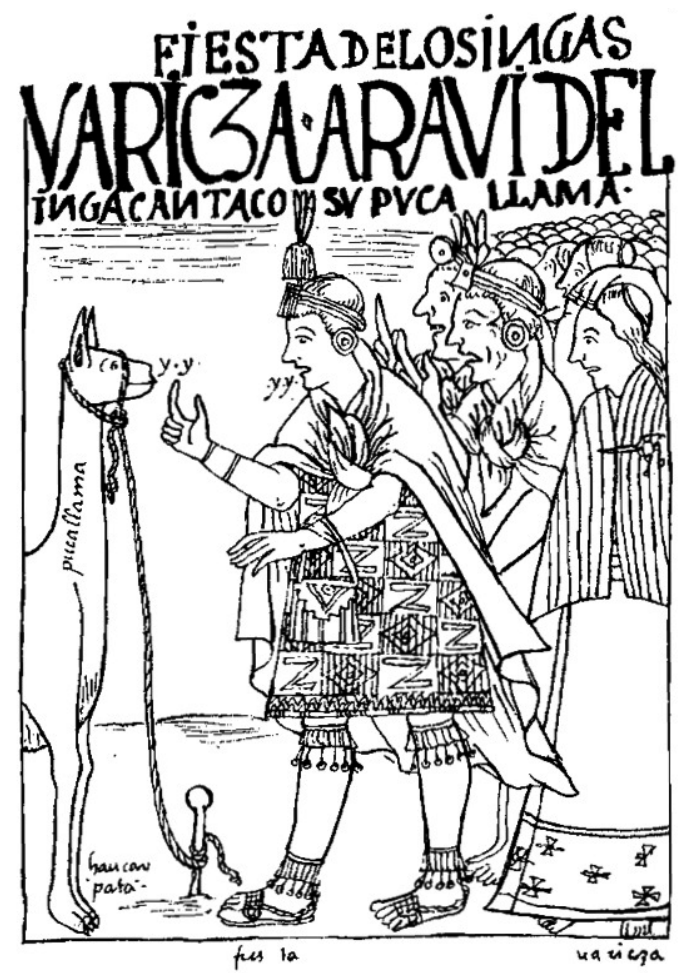

Figura 3. Fiesta de los 'Ingas', Guamán Poma 1615 (Adorno 1987:227).

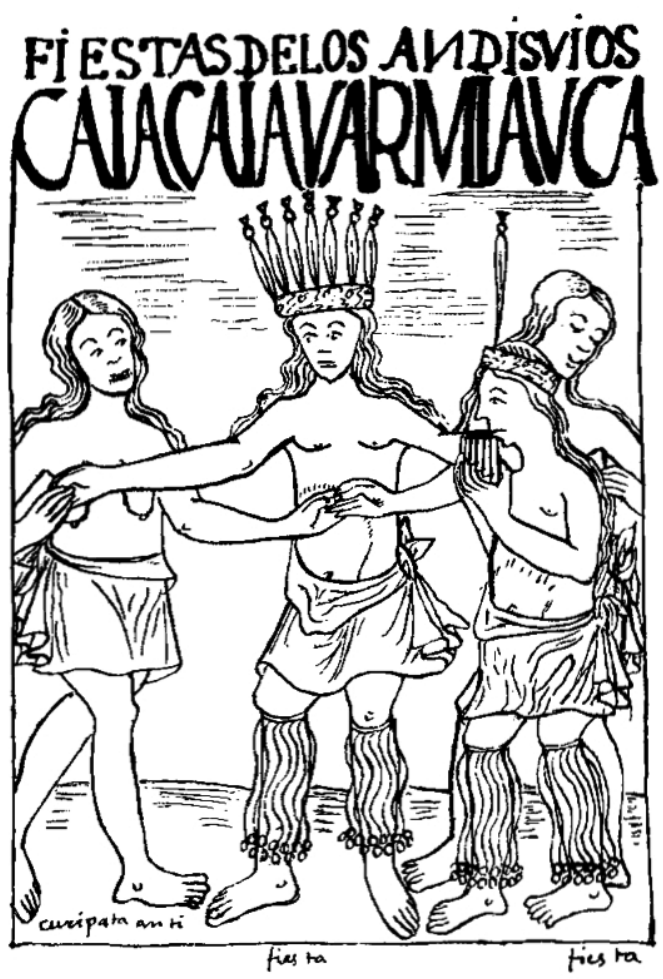

Figura 4. Fiesta de los 'Andesuyos' o Antisuyu, Guamán Poma 1615 (Adorno 1987:230).

por el uso distintivo de gorros troncocónicos y hemisféricos por parte de los hombres (propio de los Carangas y Pacajes), homogeneizando a los habitantes de este amplio territorio que abarca toda la meseta del Collao (Horta 2011).

Los siglos siguientes al XVI, impulsados por el encuentro con el Nuevo Mundo -con su flora, fauna, habitantes y tradiciones que diferían radicalmente de lo conocido-, desarrolló un modelo de conocimiento empírico que se preocupó de estudiar lo diferente; donde destacan los trabajos fundacionales de René Descartes y Francis Bacon. El nuevo método científico consistía en analizar las partes constitutivas de las cosas, para luego compararlas y establecer "series" coherentes; sin embargo, en muchos casos, los resultados solo reflejaban los intereses de la propia investigación y los prejuicios de la época. Un hito importante ocurre en 1735, cuando se publica la obra del naturalista sueco Carl Linneo "El sistema de la naturaleza"; donde desarrolla un sistema de clasificación de todas las formas vegetales del planeta, conocidas o desconocidas y que, después, se aplicarán al mundo 


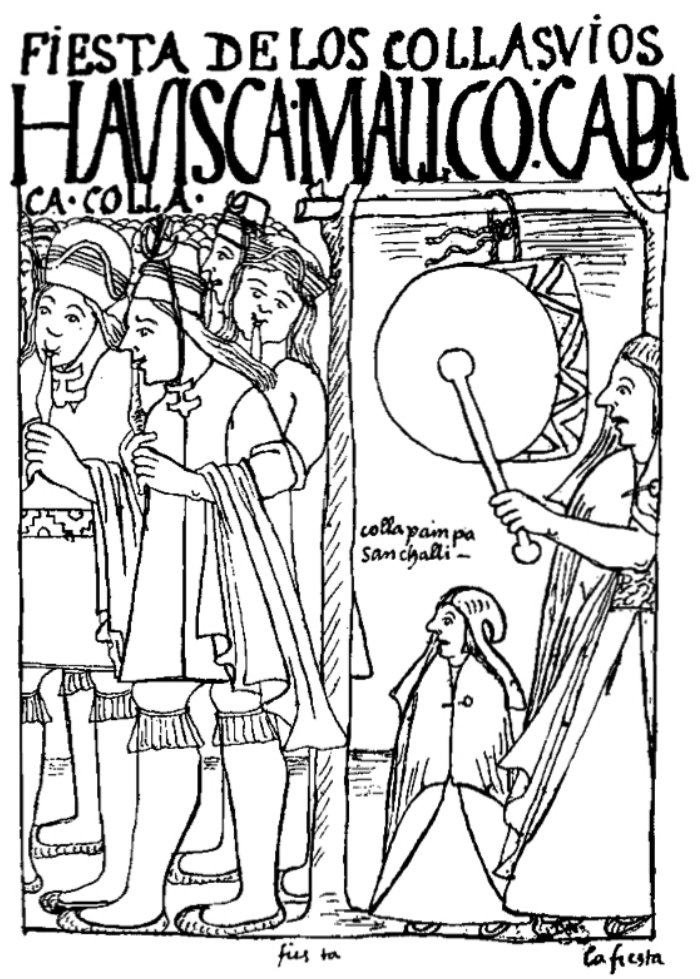

Figura 5. Fiesta de los 'Collasuyus', Guamán Poma 1615 (Adorno 1987:232).

animal. Al año siguiente se desarrolla la primera expedición científica moderna en tierras americanas: la "Misión Geodésica a la real Audiencia de Quito" (1736-1744), que tuvo la tarea de determinar la forma exacta de la Tierra. Un triunfo diplomático europeo, pues significó la apertura de un territorio herméticamente cerrado por España, quien se negaba a aceptar expediciones extranjeras. Lo que evidencia el poder de la ciencia y el interés que suscita entre sus gobernantes, como para superar rivalidades históricas. En la segunda mitad del siglo XVIII la exploración científica se convertiría en un imán de intelectuales y comerciantes de toda Europa y un foco de intenso interés público. A partir de esta fecha, la Historia Natural se vuelve un proyecto universal de clasificación y ordenación de un mundo ya conquistado, pero aún desconocido en su interior (Pratt 1997; Poole 2000).

De esta manera, la Historia Natural se transforma en una estrategia de clasificación del mundo, que saca a la naturaleza de su "caos natural", ubicando al hombre europeo dentro de este sistema global en superioridad al hombre americano y su naturaleza, como lo expuso el conde de Buffon-Georges Louis
Leclerc-en su Historia Natural, general y particular, publicada en varios volúmenes, entre 1749 y 1788 . Por tanto, al cambiar el sistema de clasificación cambia también el proyecto de dominación; es decir, antes las comparaciones y descripciones iban enfocadas a la exploración marítima, la circunnavegación y la cartografía, con el objetivo de nombrar y poseer los territorios encontrados. En cambio, la Historia Natural busca registrar y clasificar la naturaleza al interior del dominio, tarea que es llevada a cabo por iniciativa de las nuevas élites comerciales en alianza con la ciencia (Pratt 1997).

A partir de la publicitada "Misión Geodésica a la Real Audiencia de Quito" (1735-39), liderada por Charles Marie de La Condamine, se iniciaron algunas ideas, actitudes, impresiones y conocimientos de los Andes y los Incas, que tuvieron como hito principal la publicación Relación abreviada de un viaje hecho por el interior de la América Meridional (1745), por La Condamine. Una narración que, en su primera mitad, describe la flora, fauna, geología, poblados y "naciones indias", que el científico francés observó en su viaje a lo largo de la ribera del Amazonas y sus afluentes. Y que es complementada con una carta, en la que se describe el asesinato del cirujano Seniergues -miembro de la expedición- y un mapa del Amazonas. Fue este suceso trágico, y no sus actividades científicas, la que interesó tanto a la prensa -quien la publicó en primera plana- como al creciente público lector francés que pertenecía a una burguesía relativamente nueva y educada. Producto del éxito de esta obra se populariza el discurso de una América sensible, tolerante y de buen gobierno (justa), que fue destruida por los bárbaros españoles (fomentando los sentimientos protonacionalistas antiespañol). En 1778 se realiza una segunda edición ampliada de la Relación... que incluyó un grabado del "Suceso de Cuenca", donde muere el cirujano Seniergues (Figura 6). Es esencial recordar que en esa época, debido a los altos costos, era raro que los libros publicados incluyeran más de una ilustración, las que se insertaban en las primeras páginas del libro como un resumen visual. En este caso, la imagen del "Suceso de Cuenca" muestra una escena de desorden general, donde hombres con vestimentas occidentales pelean armados, en una plaza rodeada de tribunas con espectadores. También muestra a un grupo de curas que conversa en un rincón y dos leyendas numeradas en las esquinas inferiores del grabado. 


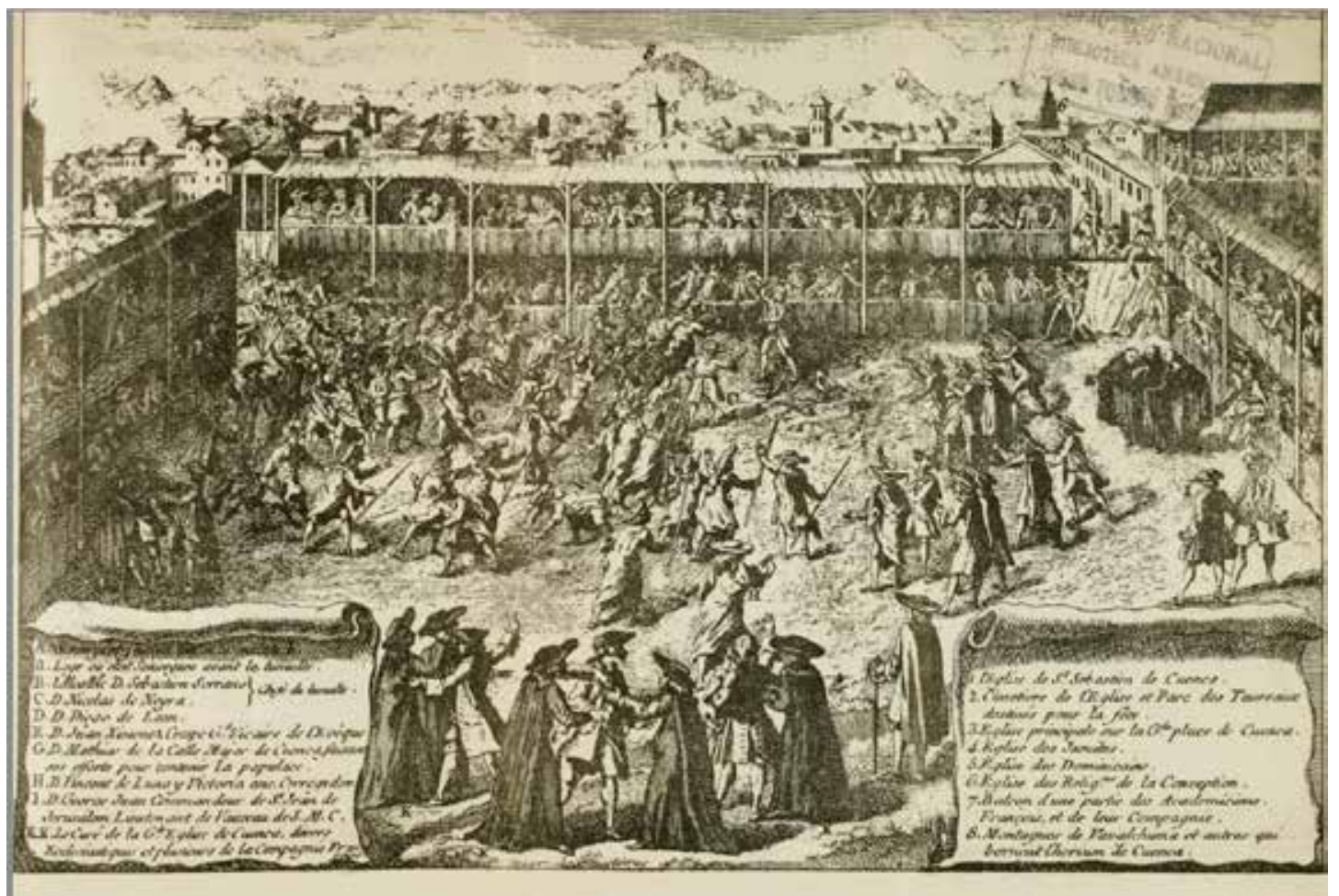

Figura 6. Suceso de Cuenca (De La Condamine 1921:159).

Esto último, dispositivos visuales ampliamente utilizados por las pinturas religiosas, que durante siglos permitieron narrar historias de martirio y santidad, y que en esa época (siglo XVIII) recién lo empezaba a utilizar la geología y la geografía en sus mapas (Poole 2000; Rowe 2003). De este modo, el mundo andino se añadió como nueva zona para la especulación filosófica e histórica, junto a Brasil, América del Norte y Oriente, en Francia.

A fines del siglo XIX el naturalista francés Alcides D'Orbigny recorre sudamérica entre 1826 y 1833. A su regreso publica L'Homme Americain, de 1839, y los nueve tomos de Voyage dans l'Amerique Méridionale, publicados entre 1835 y 1847 . Una época marcada por el auge de la imprenta y los libros, que gracias a los progresos técnicos, como la litografía, posibilitan la impresión de un mayor número de ejemplares; así como también de versiones ilustradas populares. En 1847 D'Orbigny publicó el tomo 3/parte 1 de Voyage dans... con 51 láminas -algunas de ellas coloreadas- agrupadas en tres categorías: "vistas", "usos y costumbres", y "antigüedades"; de Brasil, Uruguay, Argentina, Chile, Bolivia y Perú. Todas ellas llevan una breve etiqueta que indica el tema de la imagen y el lugarpaís, construyendo un relato visual que mezcla el interés científico con el gusto estético y lo anecdótico del viaje. En esta publicación D’Orbigny muestra a los aymara como el único grupo étnico que habita en el altiplano boliviano; pues los uru no aparecen mencionados. Destacamos la imagen de una balsa de juncos navegando a vela en el lago Titicaca, sus ocupantes no son asociados a ningún grupo étnico, aunque visten de manera similar a los Aymaras de las otras láminas caracterizados por sus sombreros de ala recta y copa redonda aplastada (Figura 7). Un territorio que se circunscribe alrededor del lago Titicaca, invisibilizando el resto de la meseta del Collao mediante una metodología visual de clasificación fisiognómica (physiognomy) -aspecto exterior y particular-, provocando en el observador una "impresión general" a partir de sus elementos estables y recurrentes, donde el sujeto indígena es parte de un mundo inmóvil; eminentemente vegetal y geográfico (Poole 2000; Zamorano 2011).

Con la llegada de la fotografía, las representaciones indígenas para el área Centro-Sur andina aumentaron en su número pero poco en su diversidad. 


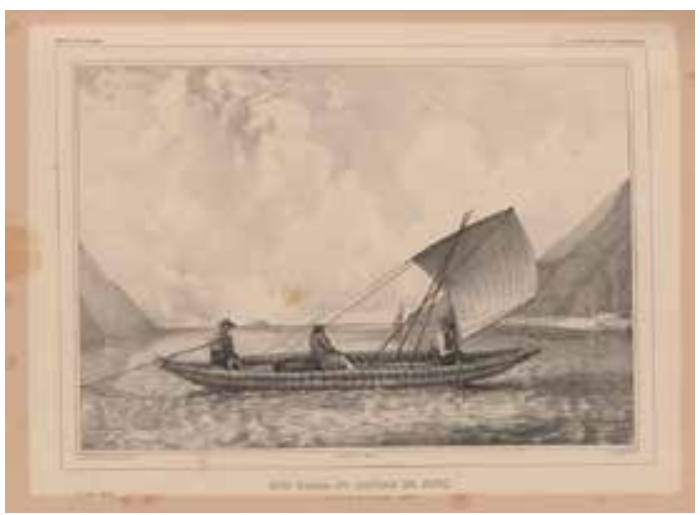

Figura 7. Balsa o bote de juncos en el lago Titicaca (Bolivia) (D’Orbigny 1847: Costumes et Usages PL. 8).

Se mantuvieron los tradicionales paisajes andinos, con sus montañas y ruinas arqueológicas, y el registro de costumbres pintorescas. Solo sufrió cambios el retrato costumbrista que se vio influenciado por las preocupaciones raciales y el desarrollo de la fotografía antropométrica hacia fines del siglo XIX. Los primeros antecedentes para la zona son las imágenes del fotógrafo francés Emile Garreaud, quien llega a Lima en 1855 y permanece en Perú hasta 1859; fecha en que cierra su estudio para establecerse en Chile, de manera definitiva, a partir de 1863 (Rodríguez 1985; Schwarz 2007). Sus fotografías étnicas, en especial aquellas tomadas en el Cuzco, tuvieron una amplia repercusión, siendo algunas de ellas publicadas en el popular Atlas Geográfico del Perú, de Mariano Paz Soldán, en 1865 (Figura 8). Una propuesta pictórica que daba cuenta de la realidad, pero embellecida y vigorizada por el arte y el sentimiento. Sin duda, un primer antecedente de un

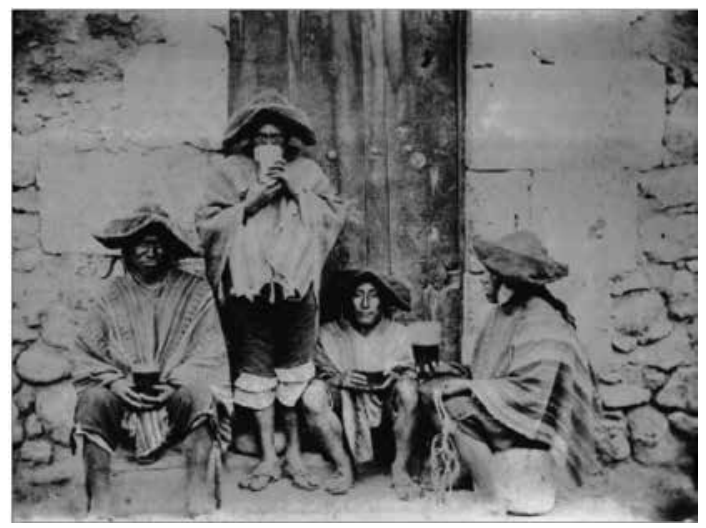

Figura 8. Indígenas de Cuzco, Emile Garreaud. Ca.1862. Archivo Cuarterolo (Trevisa y Massa 2009:45). discurso visual acerca de lo indígena, que alcanzó altos niveles de desarrollo estético y documental; primero, con la "escuela arequipeña" (1905-1914), de Maximiliano T. Vargas y otros, que enseñaron a muchos de quienes conformarían la conocida "escuela cuzqueña de fotografía" (1915-1940), cuyos exponentes más destacados fueron Miguel Chani (1915), el puneño Martín Chambi (1920) y César Meza (1940), entre muchos (Poole 2000; Trevisa y Massa 2009; Garay y Villacorta 2012).

A partir de la segunda mitad del siglos XIX, la fotografía tomó un lugar central en la nueva sociedad criolla, la invención de carte de visite (patentada por André Disdéri en 1854), un formato pequeño $(6 \times 10 \mathrm{~cm})$ que por su novedad, portabilidad y precio se convirtió en un producto masivamente producido, comercializado, intercambiado y significado. Las prácticas sociales más significativas en relación con su uso fueron el intercambio y su colección en álbumes. Estos últimos eran mostrados como evidencia de la amplitud del círculo social del propietario, una especie de moneda social o capital simbólico, capaz de portar estatus y prestigio a sus dueños. Así, la carte de visite penetró en el corazón de la cultura burguesa del siglo XIX, llegando a ser considerada en la época como "los billetes sentimentales de la civilización" (Poole 2000: 137). De este modo, la creciente burguesía europea empezó a comprar y coleccionar no solo retratos familiares, sino también fotografías de monumentos, edificios públicos, ruinas arqueológicas, obras de artes, escenas urbanas, retratos de personajes famosos, paisajes exuberantes, animales salvajes y sujetos de otras culturas; estas últimas denominadas de "tipo y costumbre". Estas fotografías eran empaquetadas y vendidas por temas, en algunos casos organizados en un relato secuencial. La fascinación pública por la cartes de visite de tipos humanos raros o exóticos creció de manera notoria a partir de 1870 , en parte gracias a que las cámaras fueron cada vez más prácticas y portátiles, lo que fomentó el viaje de muchos fotógrafos, viajeros, exploradores y los primeros etnólogos a tierras americanas (Poole 2000).

En el ámbito de las ciencias humanas, se popularizan los términos "etnografía" y "etnología", utilizados primeramente por los historiadores alemanes del siglo XVIII como August Schlözer y sus conceptos de ethnographie y völkerkunde. Conceptos que configuran una disciplina esencialista, preocupada de estudiar las culturas de lugares lejanos y exóticos en su "estado original", a partir 
de criterios de raza que construyeron identidades geoculturales definidas, acotadas e inmóviles (Giordano 2012; Zapata 2013).

Esta incipiente disciplina antropológica, bajo el amparo de la Historia Natural, desarrolló un modelo de fotografía antropométrica, en 1860, gracias a los aportes de los ingleses John H. Lamprey y Thomas H. Huxley. Para ello era necesario que el sujeto fuese fotografiado desnudo, de cuerpo entero y frente a una rejilla de hilos estandarizados o al lado de un instrumento de medición. Modelo de inscripción científica del cuerpo humano, que bajo métodos fotométricos estandarizados permitía recuperar datos morfológicos confiables y comparativos (Griffiths 1996).

A pesar de las dificultades técnicas de usar la fotografía en climas extremos y de lo pesado que era el proceso de placas húmedas de colodión, que dominó la fotografía desde 1851 hasta 1881 , fue ampliamente adoptada por viajeros y exploradores en el último cuarto del siglo XIX. Los antropólogos se convirtieron en ávidos coleccionistas de fotografías tomadas por otros, usando este tipo de fotografías para sus charlas y publicaciones, con poca atención a su procedencia específica (Griffiths 1996; Alvarado et al. 2012).

En el área Centro-Sur Andina se realizan varias expediciones o exploraciones científicas que utilizaron la fotografía como un instrumento privilegiado de registro, entre ellos destacamos al arqueólogo y escritor estadounidense George Squier (1863-1865), quien es considerado el primero en fotografiar Tiwanaku y los principales sitios sagrados en el lago Titicaca y sus alrededores (Chucuito, Sillustani, Hatuncolla -capital del Collasuyu-, Copacabana, etc.). Un relato visual que tiene al lago Titicaca como protagonista del territorio altiplánico, eminentemente arqueológico y en vinculación con la etnia Aymara por medio de sus fiestas y su religiosidad; pero con la presencia recurrente de las balsas de totora como significante privilegiado (Squier 1877; Buck 1999) (Figura 9). Entre 1868 y 1876 los geólogos alemanes Alphons Stübel y Wilhelm Reiss recorren gran parte de Sudamérica acumulando más de 2.800 imágenes bajo la lógica coleccionista que no identifica fecha ni autor, aunque es posible identificar algunos fotógrafos como los hermanos Courret, los hermanos Helsby, E. Garreaud y R. Villaalba, entre otros. Actualmente se encuentran almacenadas en el Institut für Länderkunde de Leipzig, Alemania. Otro antecedente es el austriaco, nacionalizado francés, Charles Wiener, quien viaja por Perú y Bolivia, entre

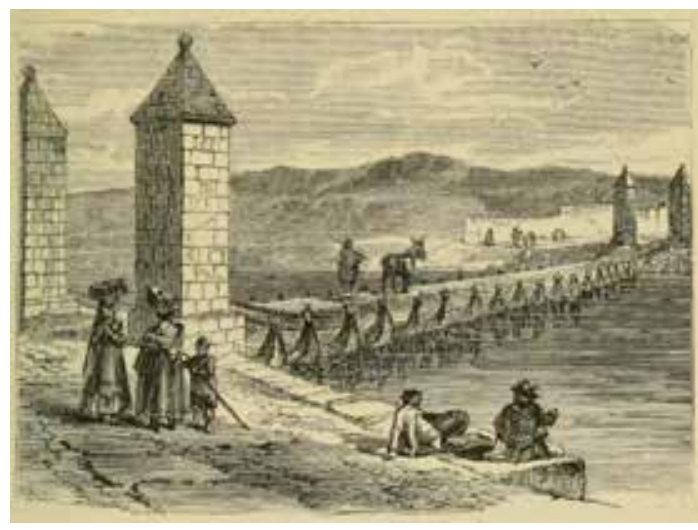

Figura 9. Puente de balsa sobre el río Desaguadero (Squier, 1877:265).

1875 y 1877, con el objetivo de recolectar objetos arqueológicos y etnográficos para la Exposición Universal de París de 1878. A su regreso publica Perú y Bolivia, narrativas de un viaje y estudios etnográficos y arqueológicos (1880), libro que incluye 1.100 grabados producidos a partir de sus propias fotografías y de otros fotógrafos como George von Grumbkow (quien había estado en Tiwanaku previamente junto a Stübel).

En 1903 se realiza la Misión Científica Francesa a la América del Sur, liderada por Georges de Créqui-Montfort y Eugène Sénechal de la Grange. Durante su estadía, que duró cerca de seis meses, se fotografiaron y midieron 208 individuos quechuas, aymaras y mestizos, número menor de lo esperado debido a la resistencia de muchos indios que incluso rechazaron dinero para permitir ser fotografiados. Para resolver esta dificultad lograron el apoyo de la mina Pulacayo -donde 103 sujetos fueron fotografiados y medidos- y de la cárcel pública de $\mathrm{La}$ Paz -de los 200 detenidos solo se pudo medir a 105 individuos-; lo que pone en evidencia el rechazo de los indígenas a la fotografía y los estrechos vínculos entre los intereses económicos, políticos y científicos. Algunas de estas fotografías, junto a otras provenientes de fotógrafos locales como los hermanos Sintitich y Ricardo Villaalba, fueron publicadas por el doctor Arthur Chervin en 1908 bajo el título Antropología Boliviana. Obra que incluye 159 imágenes con etiquetas que señalan la edad, sexualidad, lugar de procedencia y nombre del grupo indígena fotografiado. En algunos casos se indica el nombre del fotógrafo o coleccionista y, en otras, se realizan detalladas observaciones de las vestimentas utilizadas. En su gran mayoría corresponden 
a fotografías de "tipo pintorescas", que carecen de utilidad para el análisis morfométrico pero cuyas etiquetas las validan como documentos científicos. Fotografías vaciadas de su contenido semántico -o "valor de uso"-, pues solo adquieren sentido mediante los actos de propiedad, recolección, acumulación e intercambio. Al final de su obra, en el capítulo de "Fotografía Métrica", se incluyen fotografías tomadas bajo las rigurosas normas antropométricas (Figura 10). Consolidando la representación indígena como un "otro" clasificable, coleccionable y aislado de su territorio mediante el uso del telón (que oculta cualquier huella del paisaje natural o cultural). Atemporal, pues solo observamos un instante de sus vidas, sin embargo, son representativos de toda una etnia; volviéndose genéricos e indeterminados. El cuerpo es el principal objeto observado y poseído por el coleccionismo científico (Poole 2000; Giraudo y Arenas 2004; Zamorano 2011).

La popularización técnica de la fotografía, durante la primera mitad del siglo XX, abrió la posibilidad para que nuevos sujetos sociales pudieran oficiar de fotógrafos en una América aún desconocida. Así,

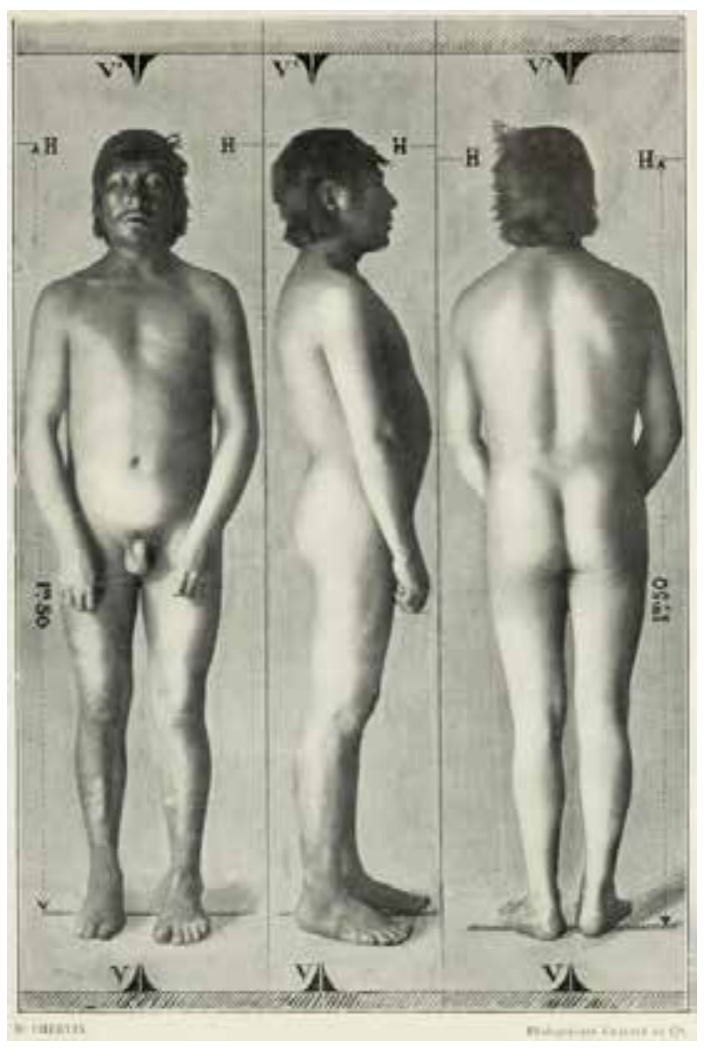

Figura 10. Quichua. Fotografía Antropométrica, Lámina 25 (Chervin 1908:336). aparecen los primeros folcloristas y etnógrafos que, con fines académicos o investigativos, fotografían profusamente paisajes, fiestas, retratos y ruinas arqueológicas andinas. Sus registros buscan ser sistemáticos y completos, por lo general carecen de valor estético aunque existen verdaderos aciertos visuales, gracias a la propia fuerza expresiva del sujeto fotografiado o al talento del fotógrafo (Alvarado et al. 2012; Palma 2013).

En 1907 se publica, en inglés y castellano, la obra Bolivia. El camino central de Sur-América, una tierra de ricos recursos y de variado interés de la escritora e historiadora estadounidense Marie Robinson Wright. Texto ricamente ilustrado con 350 fotografías, algunas de ellas compradas a fotógrafos locales, pero en su mayoría tomadas durante su viaje en 1906 por gran parte de Bolivia; auque no se sabe si es ella la autora de las fotografías, su secretaria o algún fotógrafo que la acompañaba. En el tema indígena destacan sus fotografías documentales en el mercado de Sucre, las chullpas entre Oruro y La Paz, los danzantes de la fiesta de Copacabana, las balsas de totora de los indios del Titicaca (Figura 11), las ruinas arqueológicas de "Tiahuanaco", y los diversos retratos de indígenas de La Paz, Cochabamba, Santa Cruz, Potosí, Sucre, Trinidad y el Chaco, entre otros. Una mujer famosa por sus viajes documentados por América del Sur, donde la fotografía, además de ilustrar los libros, funciona como prueba documental del "yo estuve allı"; sus relatos e imágenes dieron a conocer tempranamente la diversidad cultural de Bolivia. Para la zona del lago Titicaca señala que "su gente es distinta en carácter y rasgos aun de sus vecinos de pocas leguas de distancia, y sus botes regionales, las curiosas balsas, no son, en absoluto, como los de otras aguas" (Robinson 1907: 251).

También destacamos la figura de Arthur Posnansky -ingeniero militar austriaco, explorador y aventurero-, quien llegó para la fiebre del caucho en 1896. Posnansky se convirtió en un exitoso comerciante y después en un héroe de la Guerra del Acre (1899-1903) entre Bolivia y Brasil. Se radicó en La Paz y se dedicó a estudiar los monumentos prehispánicos y las poblaciones indígenas de Tiwanaku y sus alrededores. Sus primeras publicaciones recibieron duras críticas de Max Uhle, lingüista y arqueólogo alemán, quien estudió en profundidad Tiwanaku a partir de las fotografías y medidas tomadas por Stübel en 1876-77. Sin embargo, con los años, Posnansky logró obtener un reconocimiento en la comunidad 


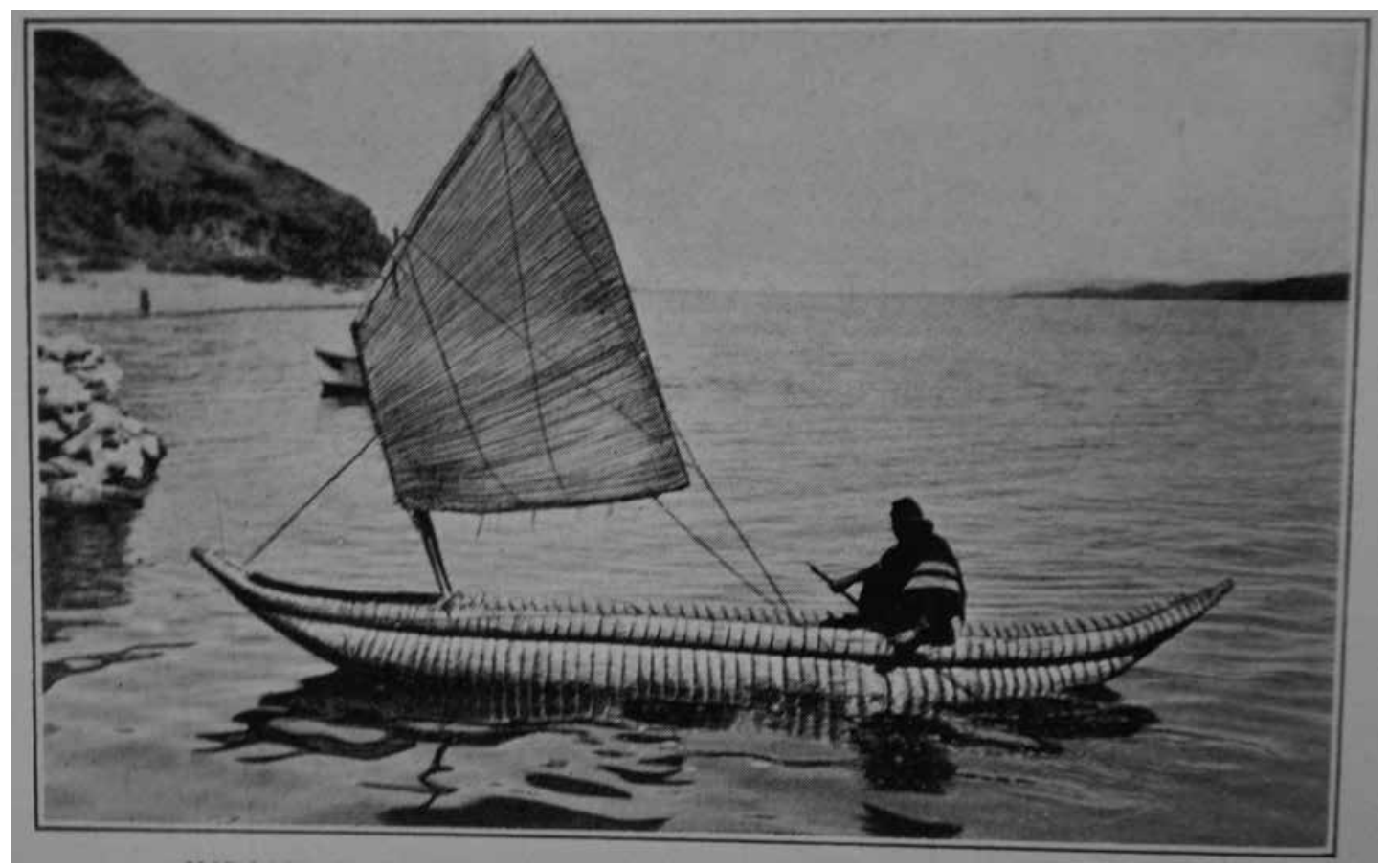

Figura 11. Indígena remando su "balsa” en el lago Titicaca (Robinson 1907:252).

científica internacional gracias a sus constantes descubrimientos, que difundía en congresos, revistas científicas y autopublicaciones, donde destaca el uso de la fotografía como principal medio de ilustración y puesta en valor (Rivet 1910). Posnansky no era un fotógrafo profesional, pero contó con la colaboración del fotógrafo y cineasta boliviano Luis Castillo González, quien tomó muchas de las imágenes arqueológicas y antropológicas publicadas por Posnasky. Entre las numerosas publicaciones de Posnansky resalta su preocupación por los indios uru, del lago Titicaca, descritos tempranamente en las distintas Relaciones Geográficas, enviadas al Rey Felipe II, en el siglo XVI, como un pueblo distinto de los Aymara y los Quechua; planteando la hipótesis de que estas comunidades fuesen vestigios de los primeros americanos (Posnansky 1912 en de Créqui-Montfort y Rivet 1927; Boulanger 2012). Por tanto, el estudio de este grupo cultural se hacía urgente, sin embargo, los uru del Titicaca, del río Desaguadero y del lago Poopó, presentaban claras muestras de sincretismo con los aymaras, quechuas y europeos; es por ello que se aventuró hacia la inhóspita provincia de Carangas, en busca de los misteriosos chipaya. En 1915 publica $L a$ lengua Chipaya, un breve texto que relata, en su introducción, las principales características de esta "raza que desde tiempos inmemoriales fue sometida y reducida por los aimaras (collas) en aquellos desiertos" (1915:1). Señala que su economía es precaria, el principal comercio es con las salitreras de Tarapacá y su vestimenta les recuerda las esculturas de Tiwanaku. Además, el autor establece una relación directa entre los "Lauraques", figuras de metal que llevan las mujeres casadas en su pelo trenzado, y los hallazgos arqueológicos en Tiwanaku, isla del Titicaca y las chullpas del altiplano; concluyendo que "los Chipayas son restos de una antiquísima raza autóctona, son, se puede decir, con sus usos étnicos, tradición y costumbres, un trozo viviente de la América prehistórica" (1915:3). El texto incluye cinco fotografías de gran tamaño y calidad técnica (nitidez), cuatro de ellas son retratos raciales de frente y perfil sobre un fondo neutro tomadas bajo estándares unificados de la Convención de Mónaco de 1906. El uso destacado y casi exclusivo de este tipo de fotografías científicas, sin duda, son reflejo de su interés por legitimarse como científico mediante su principal hallazgo: haber encontrado las raíces del hombre americano (Posnansky 1915 y 1918; Poole y Zamorano 2012). En 1918 publica Los Chipayas de Carangas, un texto que fundamenta, mediante 
elementos culturales y fisiológicos, su hipótesis de que los chipayas (de cráneo dolicocéfalo-alargado) son descendientes de los primeros habitantes del mundo andino, distintos de los aymara y los quechua (de cráneo braquicéfalo-redondo). La portada (Figura 12), al igual que la publicación anterior, tiene una fotografía con un sujeto de perfil; en este caso es un hombre de "tipo puro" (Posnansky 1918)

En 1925, Robert Gertsmann, un ingeniero eléctrico de origen ruso (con estudios en Berlín, Alemania), que llegó a Chile en 1924, decide partir de Valdivia con dirección a Antofagasta y La Paz, dejando atrás su actividad de ingeniero para convertirse en un fotógrafo viajero. Recorrió Bolivia minuciosamente entre 1925 y 1928, atravesando y fotografiando el Altiplano, el Yungas, Cochabamba, el Beni y los espacios fronterizos de Chile y Argentina; solo Tarija y el Chaco se salvaron de su lente. Sus conocimientos técnicos y formales le permitieron construir imágenes equilibradas y armónicas con notable manejo de la luz y la composición, las que

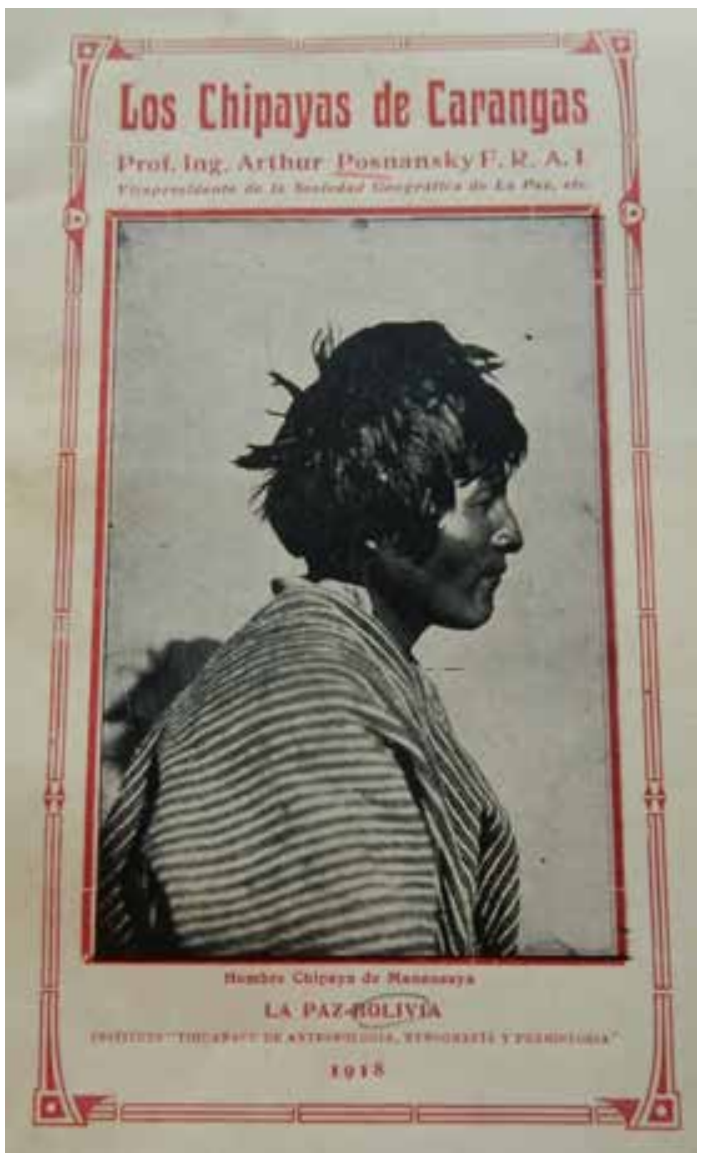

Figura 12. Portada “Los Chipayas de Carangas” (Posnansky 1918). fueron rápidamente publicadas a nivel internacional por la National Geographic Magazine (1927), ilustrando el artículo de Stewart McMillan The Heart of Aymara Land. Posteriormente en París (1928), en formato de álbum -a la usanza de los varios libros de viajes de estudiosos y exploradores europeos en el siglo XIX-, publica Bolivia 150 grabados en cobre (Buck 1999; Alvarado, Matthews y Möller 2009). Registró cerca de 5.000 imágenes durante su estadía en Bolivia, entre ellas destacamos el registro entre los chipayas de Coipasa -al sur de la provincia de Carangas-, respecto de los cuales señala: "Esta tribu constituye un enigma etnográfico: su origen es desconocido, su idioma no tiene parientes en el continente y todo el carácter de esos habitantes de los salares es un problema insoluble [...] A pesar de la naturaleza tan agreste, la índole del Chipaya es más asequible que la de sus vecinos, los Aymaras. Los Chipayas son amistosos, amables y alegres" (Gerstmann 1928:3). En su álbum de 1928, Bolivia, 150 grabados en cobre, solo incluye dos (2) fotografías de este grupo étnico, una de un grupo de mujeres frente a su vivienda circular y otra de dos mujeres (Figura 13), donde destacan sus peinados, rostros e indumentaria. Gran parte de sus fotografías se encuentran en la Universidad Católica de Antofagasta y en el Museo Chileno de

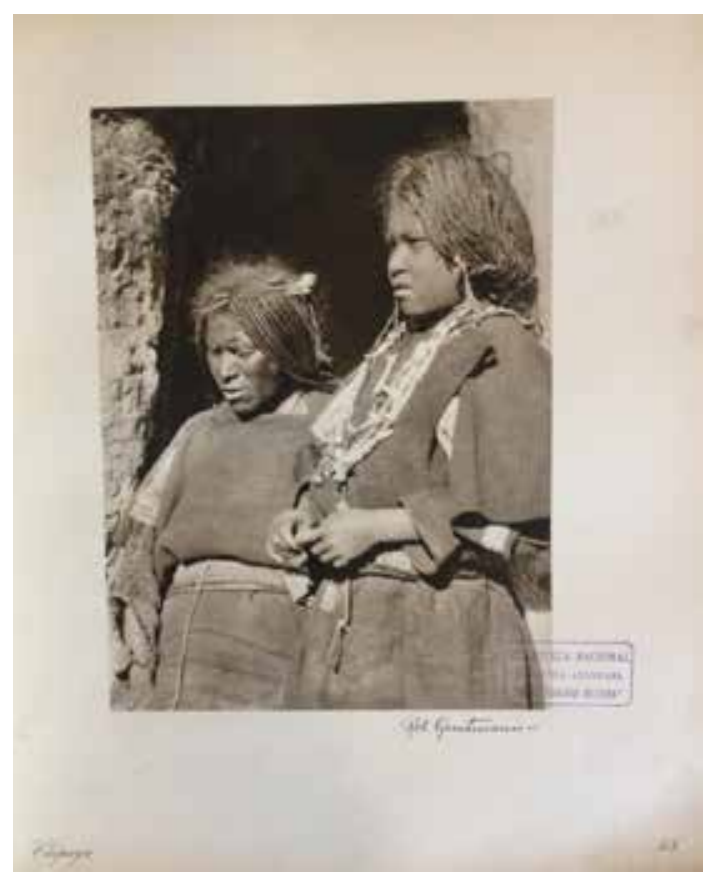

Figura 13. Mujer chipaya con su hija (Gerstmann 1928:48). 
Arte Precolombino, donde encontramos cerca de 150 imágenes de chipayas tomadas por R. Gerstmann en 1925, aproximadamente, retratando el paisaje, el poblado, sus viviendas circulares, las actividades domésticas y los propios chipayas -algunos de ellos de frente y perfil-. Finalmente, nos llama la atención una fotografía donde un grupo de mujeres observan una fotografía entregada, seguramente, por el propio Gerstmann (Figura 14). No sabemos qué mostraba esta fotografía, sin embargo, podemos ver el interés de estas mujeres por las imágenes y que, sin duda, tuvieron repercusiones en la forma en que este grupo cultural se relacionará con este artefacto visual en el futuro.

\section{Giro Representacional, la fotografía etnográfica de Alfred Métraux entre los Chipaya de Carangas}

Entre 1920 y 1930 el concepto de "fotografía documental" se comenzó a utilizar, preferentemente, para designar aquellas imágenes que hacían referencia al paisaje social, algunas de las cuales pueden considerarse verdaderas obras de arte por su lograda intencionalidad estética. Más allá del registro "puro" del referente, los fotógrafos profesionales, en expresiones cada vez más locales, van comprendiendo las posibilidades de representación e independencia del medio fotográfico. Sin abandonar la realidad circundante, miran desde otros ángulos y otras luces con una notoria participación de la creatividad. Es una fotografía más analítica y consciente de sí misma. Estética visual que se aleja de la fotografía de "tipos y costumbres", propia del siglo XIX e inicios del siglo XX, vinculándose con

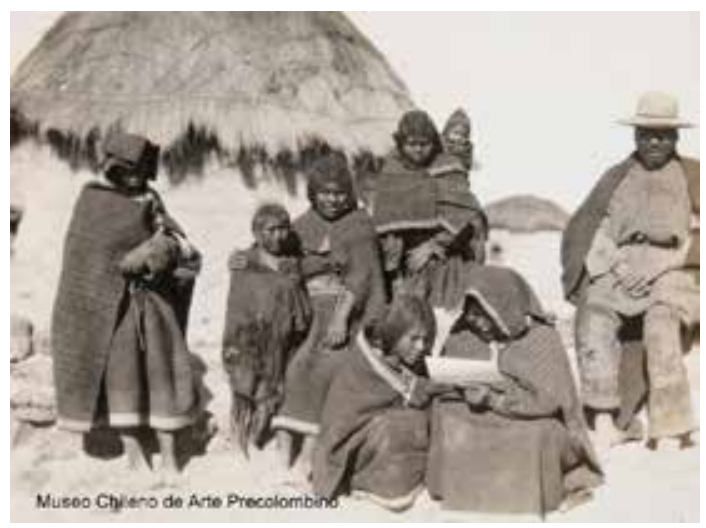

Figura 14. Grupo chipaya viendo fotografía. R. Gerstmann, Ca.1925 (Museo Chileno de Arte Precolombino, CRG090). nuevas corrientes sociales, artísticas e intelectuales, como el documentalismo y el indigenismo (Alvarado y Möller 2009; Boulanger 2012).

Entre diciembre de 1930 y abril de 1931 Alfred Métraux -un destacado etnólogo suizo, discípulo de Paul Rivet y Marcel Mauss en Francia y de Erland Nordenskiöld en Suecia- realiza una expedición al altiplano boliviano. El objetivo de esta expedición es recoger vocabulario y textos en idioma chipaya, con el fin de comprobar la hipótesis de Paul Rivet, quien sostiene que los uru-chipaya son del grupo lingüístico arawak; rama ampliamente difundida en América del Sur-desde las Antillas al norte hasta Paraguay por el sur y desde la Amazonía por el oeste hasta los contrafuertes andinos orientales-que cumplió un papel destacado en la difusión cultural en América meridional. Lo particular de los chipaya es que su lengua aún se encuentra viva, no así entre los otros grupos uru donde existen unos poco hablantes pasivos y con un vocabulario de carácter residual. Por tanto, los chipayas son los últimos vestigios de estos primeros pobladores americanos cuyo estudio se hace urgente.

Un número importante de estas fotografías, tomadas por Alfred Métraux entre los chipaya en 1930-31, se encuentran en el Museo quai Branly (París, Francia); en total son 211 imágenes de los chipaya que forman parte de la colección Métraux que tiene 3.589 registros iconográficos (Maturana 2011). Entre las 211 fotografías de chipaya se observa un buen manejo de la composición (distribución de los elementos en el campo visual), de la exposición (uso de la luz) y de la profundidad de campo (posibilidad de dejar solo algunos elementos en foco). Así como también un número importante de fotografías fuera de foco o mal encuadradas, lo que nos permite inferir que Alfred Métraux era un fotógrafo que experimentó con la fotografía como lenguaje. Las fotografías de Alfred Métraux, entre los Chipaya (1930-31), se caracterizan por ser una cámara cercana, que se adapta a la situación o acción fotografiada evitando una intervención notoria. Su cercanía con los sujetos representados, donde abundan los primeros planos y planos medios, junto con la actitud de los fotografiados, muchos de los cuales sonríen, demuestran por un lado el rol activo de los fotografiados, quienes aprobaron y apoyaron el trabajo de Métraux, y por el otro lado demuestran la exitosa estrategia de acercamiento etnográfico.

Alfred Métraux, en su afán de querer rescatar las antiguas prácticas de los distintos pueblos indígenas y 
romper con la imagen falsa y superficial del indígena -tanto la idealizada como la discriminatoria-utilizó la fotografía como una potente herramienta de registro y difusión. Utilizó la cámara como cuaderno de apuntes, con la libertad propia de la etnografía, pues a su juicio "no hay método en etnografía [...] Todo su arte se reduce a una perpetua adaptación a los hombres y a las circunstancias" (Métraux 1925:289). Fomentó una ciencia basada en la observación rigurosa, donde la fotografía no debía buscar héroes ni aventura, sino realizar un registro de lo habitual; de lo ordinario. Sin embargo, en muchas de sus tomas se observa una intencionalidad, expresadas en un encuadre inclinado, en un fondo desenfocado que concentra nuestra atención o en el registro de una situación sin valor informativo, pero de gran emotividad visual (Figura 15). Al igual que las vanguardias y el indigenismo de principios del siglo XX, Métraux experimentó con el lenguaje visual, mezclando géneros que le permitieron dinamizar un anquilosado paradigma representacional antropológico-museográfico, que tenía relegadas a las comunidades indígenas a un tiempo pasado permanente. Indagó en el registro documental de las actividades cotidianas y rituales, en favor de una foto-etnografía capaz de registrar gracias a sus cualidades polisémicas- algo más que la realidad; una "surrealidad" o "realidad superior".

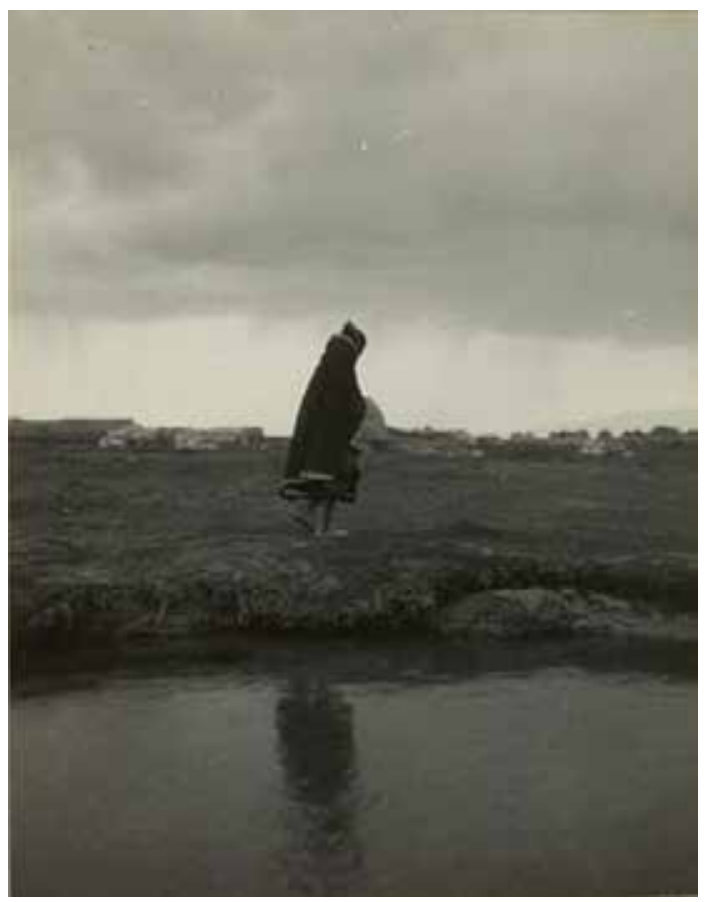

Figura 15. Mujer buscando agua bajo un cielo amenazante. Alfred Métraux, 1930-31 (Métraux 1935:PL. XIII).

\section{Comentarios Finales}

La fotografía etnográfica de Alfred Métraux jugó un rol activo en la reconfiguración del imaginario indígena en los Andes Centro-Sur, reactivando los procesos de memoria al interior de la comunidad Chipaya que participó activamente en la producción de las fotografías; algunas de las cuales tuvieron una destacada influencia en las vanguardias intelectuales y artísticas de la época, producto de su belleza composicional y fuerza referencial (Figura 16).

Una "fotografía documental" preocupada de ir más allá del registro "puro" del referente, mediante una mirada que busca observar la realidad circundante desde otros ángulos y bajo otras luces con una notoria participación de la creatividad. A nivel más conceptual, podemos señalar que la fotografía etnográfica es más que una imagen de un "otro", es un espacio de negociación de poder y de identidades, de reflexión teórica y metodológica,

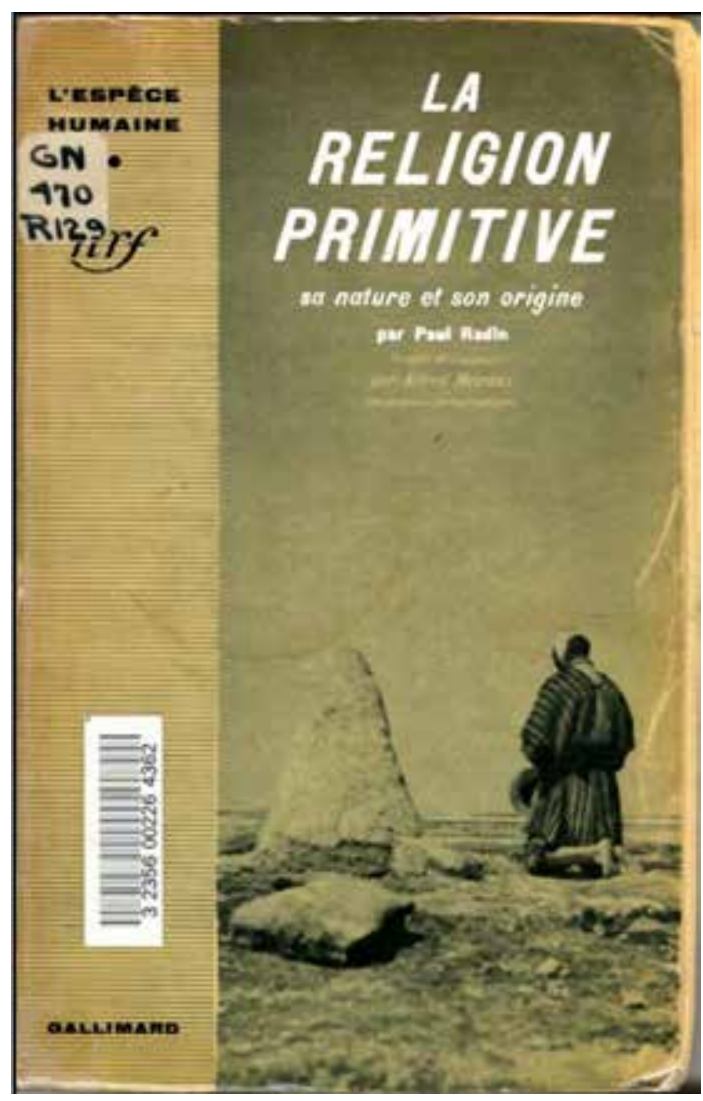

Figura 16. Indígena chipaya. fotografía de Alfred Métraux 1930-31. Portada del libro Religión primitiva, su naturaleza y su origen (Radin 1941: Portada). 
un medio de comunicación intercultural y un vínculo social. Un lugar de cruce de miradas, entre el fotógrafo-etnógrafo que encuadra y produce la imagen, un fotografiado-indígena que interactúa con el fotógrafo-etnógrafo, y el espectador que interpreta la imagen; una fotografía etnográfica no es más que un trozo de papel si no hay una mirada sobre ella. Rompiendo aquella tradicional idea que piensa a la imagen como una copia de una cosa, "cosificación de la imagen" que nos hace olvidar que la imagen en realidad es un acto (intercultural) que debe ser revelado. Pensar la fotografía desde la mirada es reconocer que las imágenes no son neutras ni unívocas, pues todo lo que sabemos, o lo que creemos, afecta al modo en que vemos las cosas. La imagen ya no se entiende como una simple representación de la realidad, sino como productora de una nueva realidad mediada técnicamente por un instrumento que no es transparente ni neutro. La imagen ya no es la evidencia de un mundo material sino una realidad en sí misma, un fenómeno intersubjetivo en la que la emotividad, la narratividad y los efectos de la comunicación juegan un rol esencial.

La tarea de los investigadores preocupados de la imagen es encontrar estos archivos o colecciones olvidadas, contextualizarlos, analizarlos y proponer nuevas lecturas que dialoguen con el imaginario social para su reactualización y conformación de una memoria pública y democrática acerca de la alteridad indígena.

\section{Referencias Citadas}

Adorno, R.

1987 Sobre el lenguaje pictórico y la tipología cultural en una crónica andina [en línea]. Chungara, Revista de Antropología Chilena, Departamento de Antropología, Universidad de Tarapacá, Arica, Chile, agosto, Vol. 18, pp. 101-144.

Alvarado, M.; Mege, P.; Bajas, M.P. y Möller, C.

2012 Andinos. Fotografías siglos XIX y XX. Visualidades e imaginarios del desierto y el altiplano. Santiago, Chile, Pehuén Editores.

Alvarado, M.; Matthews, M. y Möller, C.

2009 Roberto Gerstmann. Fotografías, paisajes y territorios latinoamericanos. Santiago, Pehuén Editores.

Alvarado, M. y Möller, C.

2009 Dentro y fuera de cuadro. Representación y alteridad en la fotografía de indígenas de Chile. [en línea] Revista Chilena de Antropología Visual, Número 14, 1-41.

Boulanger, S. (Ed.)

2012 Fotografía Boliviana. Acción Cultural, La Paz, Bolivia. Buck, D

1999 Pioneer Photography in Bolivia: Directory of Daguerreotypists \& Photographers, 1840s-1930s.

Cerrón-Palomino, R.

2006 El chipaya o la lengua de los hombres del agua. Lima, Fondo Editorial de la Pontificia Universidad Católica del Perú.

De Créqui-Montfort G. y Rivet, P.

1927 Linguistique bolivienne. La langue Uru ou Pukina. [en línea] Journal de la Société des Américanistes, Société des Américanistes. París, Francia, No 19, pp. 57-116.

Dedenbach-Salazar S., S.

2007 The andean Uru-Chipaya language. [en línea] Bonn, Universidad de Bonn y Volkswagen Foundation Project Documentation of Endangered Languages, DOBES.

D’Orbigny, A.

1847 Voyage dans l"Amérique méridionale, exécuté pendant les années 1826-1833. Tome 3, partie 1. P.Bertrand, París. https://archive.org/details/voyagedanslamriq81847orbi
Estenssoro, J.C.

2005 Construyendo la memoria: la figura del inca y el reino del Perú, de la conquista a Túpac Amaru II. En: Majluf, N. (Coord.). Los incas, reyes del Perú. Lima, Perú, Banco de Crédito. Pp. 93-173.

Garay, A. y Villacorta, J.

2012 Un arte arequipeño: maestros del retrato fotográfico. Lima, Perú, Instituto Cultural Peruano-Norteamericano.

Gerstmann, R.

1928 Bolivia, 150 grabados en cobre. París, Braun y Co Editores.

Giordano, M.

2012 Fotografía, testimonio oral y memoria. (re)presentaciones de indígenas e inmigrantes del Chaco (Argentina). Memoria Americana, Cuadernos de Etnohistoria, Instituto de Ciencias Antropológicas, Facultad de Filosofía, Universidad de Buenos Aires, Argentina. 20(2): 295-321.

Giraudo, S. y Arenas, P.

2004 Científicos europeos en el altiplano boliviano-argentino: antropología, expediciones y fotos. [en línea] Anales del Museo de América, Ministerio de Educación, Cultura y Deporte, Gobierno de España, Madrid, España, $N^{\circ} 12$, pp. 125-146.

Griffiths, A.

1996 Knowledge and visuality in turn of the century Anthropology: the early Ethnographic Cinema of Alfred Cort Haddon and Walter Baldwin Spencer. Visual Anthropology Review, Society for Visual Anthropology, American Anthropological Association. 12(2): 18-43.

Hannss, K.

2008 Uchumataqu: The Lost Language of the Urus of Bolivia. A grammatical description of the language as documented between 1894 and 1952. University Leiden-Netherlands, CNWS Publications Volume 158.

Hidalgo, J.

1978 Incidencias de los patrones de poblamiento en el cálculo de la población del Partido de Atacama desde 1752 a 1804: Las revisitas inéditas de 1787-1792 y 1804. Estudios Atacameños $\mathrm{N}^{\circ}$ 6, pp. 49-105. 
Hidalgo, J.

1982 Culturas y etnias protohistóricas: Area Andina Meridional.

En Chungara $\mathrm{N}^{\circ}$ 8. Universidad de Tarapaca, Arica, Chile. Horta, $\mathrm{H}$.

2011 El gorro troncocónico o chucu y la presencia de población altiplánica en el norte de chile durante el periodo tardío (ca. 1.470-1.536 d.c.). Chungara, Revista de Antropología Chilena, Universidad de Tarapacá, Arica, Chile. 43: 551-580.

La Barre, W.

1946 The Uru - Chipaya. En: Steward, J. (Ed.). Handbook of South American Indians. Washington, Bureau of American Ethnology-Smithsonian Institution. Vol. 2, pp. 575-585.

Martínez, J.L.

1992 Acerca de las etnicidades en Puna Árida en el siglo XVI. II Congreso Internacional de Etnohistoria, Coroico, Bolivia. Pp. 35-65.

Maturana, F.

2011 Informe Beca Movilidad Doctoral. Embajada de Francia en Chile (EGIDE/EXOS-SUD). MS.

Métraux, A.

1925 De la méthode dans les recherches ethnographiques. Revue d"Ethnographie et des Traditions Populaires. 23-24: 266-290.

Métraux, A.

1935 Civilización material de los Indios Uro-Chipaya de Caranga (Bolivia). Revista del Instituto de Etnología de la Universidad Nacional de Tucumán, Argentina. Tomo III. Pp. 85-129.

Palma, M.

2013 Fotografía de Martín Gusinde en Tierra del Fuego (1919-1924). La imagen Material y Receptiva. Santiago, Chile, Ediciones Universidad Alberto Hurtado.

Poole, D.

2000 Una economía visual del mundo andino de imágenes. Lima, Perú, Sur Casa de Estudios del Socialismo y Consejería en Proyectos.

Poole, D. y Zamorano, G. (Eds.)

2012 De frente y perfil. Retratos raciales de Frederick Starr. México D. F., México, Colegio de Michoacán y Fideicomiso Felipe Taixidor y Monserrat Alfau de Teixidor.

Posnansky, A.

1915 La Lengua Chipaya. La Paz, Bolivia, Instituto Tihuanacu de Antropología, Etnografía y Prehistoria.

Posnansky, A.

1918 Los Chipayas de Carangas. La Paz, Bolivia, Instituto Tihuanacu de Antropología, Etnografía y Prehistoria.

Pratt, M.L.

1997 Ojos imperiales. Literatura de viajes y transculturación. Buenos Aires, Argentina, Universidad Nacional de Quilmes.

Rivet, $\mathrm{P}$.

1910 Les monuments préhistoriques de Tiahuanaco [en línea] Journal de la Société des Américanistes, Mélanges et nouvelles américanistes, Vol. 7, No 1, pp. 336-336.
Robinson, M.

1907 Bolivia. El camino central de Sur-América, una tierra de ricos recursos y de variado interés. Filadelfia, Jorge Barrie y hijos Editores.

Rodríguez, $\mathrm{H}$.

1985 Registro de daguerrotipistas, fotógrafos, reporteros gráficos y camarógrafos 1840-1940. Santiago, Chile, Boletín de la Academia Chilena de la Historia. 52(96): 189-340.

Rowe, J.H.

2003 2003. Retratos Coloniales de los Incas nobles. En: Los Incas del Cuzco. Siglos XVI-XVII-XVIII. Cuzco, Perú, Instituto Nacional de Cultura. Pp. 287-306.

Saignes, $\mathrm{T}$.

1991 Lobos y ovejas, formación y desarrollo de los pueblos y comunidades en el Sur Andino (siglos XVI-XX). En: Moreno, S. y Salomón, F. (Comp.). Reproducción y transformación de las sociedades andinas siglos XVI-XX. Quito, Ecuador, Ediciones ABYA-YALA. Pp. 91-135.

Sanhueza, C.

2008 Territorios, prácticas rituales y demarcación del espacio en Tarapacá en el siglo XVI. Boletín del Museo Chileno de Arte Precolombino, Santiago, Chile, Vol. 13, No 2, pp. 57-75.

Schwarz, H.

2007 Fotógrafos franceses en el Perú del siglo XIX. Bulletin de l'Institut Français d'Études Andines. Lima, Perú, IFEA. 36(1): 39-49.

Squier, E.G.

1877 Peru, incidents of travel and exploration in the land of the Incas. New York, U.S.A., Harper \& Brothers Publishers.

Trevisa, P. y Massa, L.

2009 Fotografías cuzqueñas atravesando el indigenismo. Aisthesis, Revista de Investigaciones Estéticas, Instituto de Estética, Pontificia Universidad Católica de Chile, Santiago, Chile, 46: 39-64.

Schopik, H.

1946 The Aymara. En: Steward, J. (Ed), Handbook of South American Indians. Bureau of American EthnologySmithsonian Institution. Washington, U.S.A., Vol. 2, pp. 501-573.

Wachtel, N.

1978 Hommes d"eau: le problème uru (XVIe-XVIle siècle). Annales. Économies, Sociétés, Civilisations, $\mathrm{N}^{\circ}$ 5-6, 1127-1159.

Zamorano, G.

2011 Fisonomía de Traidor: Fotografía y la Racialización de los indígenas Bolivianos por la Expedición Créqui-Montfort (1903). Anuario de Estudios Bolivianos, Archivísticos y Bibliográficos, Sucre, Bolivia, Archivo Biblioteca Nacionales de Bolivia, $\mathrm{N}^{\mathrm{o}} 17$, pp. 635-674.

Zapata, C.

2013 Intelectuales indígenas en Ecuador, Bolivia y Chile. Diferencia, colonialismo y anticolonialismo. Quito: Ediciones Abya Yala.

\section{Notas}

1 Es importante señalar que muchas voces indígenas -como Tiwanaku, Tawantinsuyu, etc.- son escritos de manera diferente por los distintos autores aquí citados. En el presente texto se ha optado por utilizar aquellas formas escriturales más frecuentes y dejar en comillas simples las propuestas escriturales de los autores citados. 
